\title{
The AMPA Receptor Subunit GluR1 Regulates Dendritic Architecture of Motor Neurons
}

\author{
Fiona M. Inglis, ${ }^{1}$ Richard Crockett, ${ }^{1}$ Sailaja Korada, ${ }^{1}$ Wickliffe C. Abraham, ${ }^{3}$ Michael Hollmann, ${ }^{4}$ and \\ Robert G. Kalb ${ }^{1,2}$ \\ Departments of ${ }^{1}$ Neurology and 2 Pharmacology, Yale University School of Medicine, New Haven, Connecticut \\ 06520-8018, 32Department of Psychology, University of Otago, Dunedin, New Zealand, and ${ }^{4}$ Department of Biochemistry \\ I-Receptor Biochemistry, Ruhr University Bochum, D-44780, Bochum, Germany
}

The morphology of the mature motor neuron dendritic arbor is determined by activity-dependent processes occurring during a critical period in early postnatal life. The abundance of the AMPA receptor subunit GluR1 in motor neurons is very high during this period and subsequently falls to a negligible level. To test the role of GluR1 in dendrite morphogenesis, we reintroduced GluR1 into rat motor neurons at the end of the critical period and quantitatively studied the effects on dendrite architecture. Two versions of GluR1 were studied that differed by the amino acid in the "Q/R" editing site. The amino acid occupying this site determines single-channel conductance, ionic permeability, and other essential electrophysiologic properties of the resulting receptor channels. We found large-scale remodeling of dendritic architectures in a manner depending on the amino acid occupying the $\mathrm{Q} / \mathrm{R}$ editing site. Alterations in the distribution of dendritic arbor were not prevented by blocking NMDA receptors. These observations suggest that the expression of GluR1 in motor neurons modulates a component of the molecular substrate of activity-dependent dendrite morphogenesis. The control of these events relies on subunit-specific properties of AMPA receptors.

Key words: activity-dependent development; motor neuron; dendrite; glutamate receptor; AMPA receptor; NMDA receptor; RNA editing; spinal cord
Dendrites play a decisive role in the computational work of neurons within the vertebrate CNS. The size and complexity of the dendritic arbor influences this process in several ways (Hausser et al., 2000). Dendritic morphology impacts on the electrical and chemical compartmentalization of signals received by a neuron (Spruston et al., 1995; Segev, 1998; Helmchem, 1999; Magee, 1999; Nusser, 1999; Vetter et al., 2001) and thereby impacts on neuronal information processing (Mainen and Sejnowski, 1996; Korogod et al., 2000; Wei et al., 2001). In addition, dendritic morphology influences the number and types of synaptic inputs into neurons (Hume and Purves, 1981; Purves and Hume, 1981; Purves, 1983). In light of the profound ways that dendritic architecture influences the input-output relationships of the neuron, it is not surprising that the factors controlling dendrite development are under intense scrutiny (Stuart et al., 1999).

Although the initial extension of dendrites occurs soon after neurogenesis and neuronal migration (Jackson and Frank, 1987),

Received April 2, 2002; revised May 29, 2002; accepted June 6, 2002.

This work was supported by grants from the National Institutes of Health (NS29837 and NS33467) and NASA (NAG2-951) to R.G.K. and a Health Research Council of New Zealand program grant to W.A. We thank Dr. Rachael Neve (Department of Genetics, Harvard Medical School, Boston, MA) for packaging the viruses used in this study and Dr. James Howe (Department of Pharmacology, Yale Medical School, New Haven, CT) for critical comments on these experiments and this manuscript. We thank Sara E. Mason-Parker (University of Otago) for expert technical assistance.

Correspondence should be addressed to Dr. Robert G. Kalb, Department of Neurology, University of Pennsylvania School of Medicine, Children's Hospital of Philadelphia, Neurology Research, Abramson Research Building, 34th Street and Civic Center Boulevard, Philadelphia, PA 19104. E-mail: kalb@email.chop.edu.

F. Inglis's present address: Department of Cell and Molecular Biology, Tulane University, New Orleans, LA 70118.

S. Korada's present address: Child Study Center, Yale University School of Medicine, New Haven, CT 06520.

Copyright (C) 2002 Society for Neuroscience $0270-6474 / 02 / 228042-10 \$ 15.00 / 0$ dendrites continue to grow and change after birth in coordination with the establishment of precise interneuronal synaptic communication. This raises the possibility that synaptic activity may influence dendritogenesis, an idea confirmed in various developmental situations throughout the neuroaxis (Katz and Constantine-Paton, 1988; Bodnarenko and Chalupa, 1993; Kalb, 1994; McAllister et al., 1995, 1997; Rajan and Cline, 1998). Two salient features of activity-dependent sculpting of the dendritic arbor have emerged (Shatz, 1990; Goodman and Shatz, 1993): (1) large scale changes in dendrites occur during a critical period in early postnatal life on a time scale of days or weeks, and (2) activitydependent plasticity involves excitatory neurotransmission and the activation of glutamate receptors.

What molecular mechanisms subserve activity-dependent development of dendrites during a critical period of postnatal development? Previous work has shown that spinal motor neurons undergo glutamate receptor-mediated activity-dependent development (Kalb and Hockfield, 1990; Inglis et al., 1998). During this critical period, the repertoire of glutamate receptors expressed by developing motor neuron differs significantly from the glutamate receptor phenotype of mature motor neurons (Kalb et al., 1992; Stegenga and Kalb, 2001). For example, neonatal, but not adult, motor neurons express very high levels of the GluR1flip subunit of the AMPA-type glutamate receptors (Jakowec et al., 1995a,b). The pharmacological and electrophysiological signature of GluR1-containing AMPA receptors is found in neonatal motor neurons, confirming the functional contribution of this subunit (Carriedo et al., 1996; Bar-Peled et al., 1999; Vandenberghe et al., 2000a,b). This subunit is the "flip" isoform (Jakowec et al., 1995b) and contains a glutamine at the site that in the AMPA receptor subunit GluR2 is the critical Q/R RNA editing site known to control calcium permeability and current-voltage $(I-V)$ relation- 
ships (Sommer et al., 1991; Burnashev et al., 1992; Jonas et al., 1994).

To test the hypothesis that expression of GluR1 in motor neurons is a determinant in establishing dendritic morphology, we used viral vectors to express GluR1flip in motor neurons (Neve et al., 1997) when endogenous GluR1flip expression had reached low levels (Jakowec et al., 1995a,b) and the dendritic tree had achieved its mature architecture (Kalb, 1994). Furthermore, to investigate the involvement of specific electrophysiological properties of AMPA receptor signaling, such as calcium permeability, we used two constructs: naturally occurring GluR1(Q)flip, and a mutant GluR1(R)flip.

\section{MATERIALS AND METHODS}

cRNA synthesis. cRNA synthesis was performed as described earlier (Hollmann et al., 1994). Briefly, template cDNA was linearized with a suitable restriction enzyme, and cRNA was prepared from $1 \mu \mathrm{g}$ of linearized cDNA using an in vitro transcription kit (Stratagene, Heidelberg, Germany). The standard protocol was modified such that each nucleotide was used at $800 \mu \mathrm{M}$, except for GTP $(200 \mu \mathrm{M}) ; 400 \mu \mathrm{M}$ ${ }^{\mathrm{m} 7} \mathrm{GpppG}$ was included for capping. The reaction time was extended to 3-4 hr using $\mathrm{T} 7$ polymerase. Trace labeling was performed with $\left[{ }^{32}\right.$ P]UTP (Amersham, Braunschweig, Germany) to allow calculation of yields and transcript quality check by agarose gel electrophoresis.

Electrophysiological recordings from Xenopus oocytes. Using a Drummond microdispenser, $50 \mathrm{nl}$ of cRNAs was injected into oocytes of stages $\mathrm{V}-\mathrm{VI}$ that had been removed from the ovaries of Xenopus laevis as described elsewhere (Everts et al., 1997). Four to eight days after cRNA injection, two-electrode voltage-clamp recordings were performed with a TurboTec 10CD amplifier (npi, Tamm, Germany) by superfusion of the oocytes with glutamatergic agonists $(100-300 \mu \mathrm{M})$ prepared in normal frog Ringer's solution containing (in $\mathrm{mM}$ ): $115 \mathrm{NaCl}_{1} 1.5 \mathrm{CaCl}_{2}, 2.5 \mathrm{KCl}$, 10 HEPES-NaOH, pH 7.2. Current electrodes were filled with $3 \mathrm{M} \mathrm{CsCl}$ and had resistances of $\sim 0.5-1.5 \mathrm{M} \Omega$. Voltage electrodes were filled with $3 \mathrm{M} \mathrm{KCl}$ and had resistances of $\sim 4 \mathrm{M} \Omega$. Oocytes were held at $-70 \mathrm{mV}$, and agonists were applied for $20 \mathrm{sec}$ at a flow rate of $10-14 \mathrm{ml} / \mathrm{min}$. Current-voltage relationships were determined with $2 \mathrm{sec}$ voltage ramps from $-150 \mathrm{mV}$ to $+50 \mathrm{mV}$. Calcium permeability was tested by performing current recordings in calcium-Ringer's $\left(80 \mathrm{mM} \mathrm{CaCl}_{2}\right.$ and $10 \mathrm{~mm}$ HEPES, pH 7.2, adjusted with $N$-methyl-D-glucamine). Recordings from oocytes heterologously expressing glutamate receptors (either GluR1(Q)flip or GluR1(R)flip alone or combined) were replicated between 3 and 11 times. Representative single traces from individual glutamate receptor-expressing oocytes are shown in Figure 2.

Site-directed mutagenesis. Single nucleotide exchanges were introduced by PCR-mediated site-directed mutagenesis using mutagenetic primers as described previously (Hollmann et al., 1994). All mutations were verified by chain-termination method sequencing using the Sequenase kit from USB.

Preparation of viral vectors. Viral constructs were made using the Herpes simplex virus (HSV) amplicon system, as described previously (Neve et al., 1997). Rat GluR1(Q)flip, rat GluR1(R)flip, and LacZ cDNAs were inserted into HSV amplicon HSV-PrpUC, and the recombinant plasmids were packaged into virus particles in the cell line 2-2, using the replication-incompetent IE2 deletion mutant 5dl1.2, derived from the KOS strain, as helper virus (Lim et al., 1996; Neve et al., 1997). The virus was purified on a sucrose gradient and resuspended in sucrose. Viral titers used in these studies were $3-5 \times 10^{7}$ plaque-forming units $/ \mathrm{ml}$.

In vivo delivery of virus. Sprague Dawley rats, $23 \mathrm{~d}$ old, were anesthetized with ketamine $(50.0 \mathrm{mg} / \mathrm{kg})$ and xylazine $(4.0 \mathrm{mg} / \mathrm{kg})$. The sciatic nerve was exposed, and $\sim 3 \mu$ l of virus was injected through a microelectrode at a rate of $2 \mu \mathrm{l} / \mathrm{min}$. After removal of the microelectrode, the wound was sutured, and animals were allowed to recover from anesthesia. After $5 \mathrm{~d}$, animals were killed by perfusion fixation, and the spinal cords harvested.

One set of postnatal day (P) 23 rats was injected with HSVGluR1(Q)flip and received daily intraperitoneal injections of $1 \mathrm{mg} / \mathrm{kg}$ of MK-801 [(5R,10S)-(+)-5-methyl-10,11-dihydro-5H-dibenzo(a,d)cyclohepten5,10-imine hydrogen maleate] dissolved in normal saline or the vehicle alone. After $5 \mathrm{~d}$ the animals were killed.

In vivo electrophysiology. Male rats (P26-29) were anesthetized with urethane $(1.5 \mathrm{mg} / \mathrm{kg}$, i.p.) and prepared for electrophysiology using methods as described previously (Abraham and Mason, 1988). The animal's rectal temperature was maintained at $37 \pm 0.1^{\circ} \mathrm{C}$ using a heating lamp. A stimulating electrode was placed in the perforant path fibers of the angular bundle, which contain excitatory afferent fibers to the dentate gyrus. A recording electrode was placed in the ipsilateral hilus of the dentate gyrus to maximize the field potential evoked by single shocks of the perforant path. After stabilization of the electrode placements, constant amplitude test pulses $(150 \mu \mathrm{sec}$ pulse duration and sufficient to give a $2-4 \mathrm{mV}$ population spike) were delivered at $20 \mathrm{sec}$ intervals for 30 min before and $60 \mathrm{~min}$ after high-frequency stimulation (HFS) to induce long-term potentiation (LTP). HFS consisted of four sets of five $400 \mathrm{~Hz}$ trains ( 25 msec duration, $250 \mu \mathrm{sec}$ pulse width) spaced $1 \mathrm{sec}$ apart, with $1 \mathrm{~min}$ between sets of trains. Measurement was made of the initial slope of the field EPSP (fEPSP) for each test response. The final 30 responses before HFS were averaged to obtain a mean baseline response, and all measurements were expressed as a percentage of this mean baseline value. The last 30 responses recorded after HFS were averaged to provide an index of LTP recorded $60 \mathrm{~min}$ after HFS. MK-801 $(1 \mathrm{mg} / \mathrm{kg}$, i.p.) or its saline vehicle was administered shortly after completion of the initial surgical procedures, but $2 \mathrm{hr}$ before HFS. Because MK- 801 can by itself cause a response depression (Abraham and Mason, 1988), the stimulus strength was adjusted $30 \mathrm{~min}$ before HFS to ensure that the baseline response amplitudes were equivalent between MK-801 and control animals. Statistical comparisons were made with an independent Student's $t$ test.

Immunohistochemistry. Immunohistochemistry was performed within $2 \mathrm{~d}$ after animals were killed. The lumbar area of the spinal cord was sectioned on a vibratome $(80 \mu \mathrm{m})$, rinsed in $0.1 \mathrm{M}$ phosphate buffer, and incubated for $48 \mathrm{hr}$ with affinity-purified polyclonal rabbit antibody against GluR1 (Upstate Biotechnology, Lake Placid, NY) or LacZ (5-prime 3-prime). Sections were then rinsed in phosphate buffer and incubated for $2 \mathrm{hr}$ with biotinylated goat anti-rabbit antibody. Immunoreactivity was detected by reaction with a peroxidase-diaminobenzidine reaction (Vector). Sections were mounted on gelatin-coated slides, dehydrated, and coverslipped. Sections were viewed with Nomarski optics, and transgene-containing cells were analyzed using computer-assisted camera lucida software (Neurolucida; Microbrightfield Inc., Colchester, VT).

Experiments were performed and data were collected in a way to minimize the potential for bias. All transgene-expressing neurons from a group of nerve-injected animals were drawn by R.C. or S.K. Drawings of neurons could not be made in a completely blind manner because there is endogenous GluR1 immunoreactivity in the dorsal horn of animals at this age and no endogenous $\beta$-galactosidase immunoreactivity. When camera lucida drawings were made of motor neurons from animals injected with HSV-GluR1(Q)flip or HSV-GluR1(R)flip, the drawer was blinded.

Before any neuron drawings were made, we established a set of criteria for inclusion in this study, and only neurons fulfilling these criteria were analyzed. By only including these cells, transgene expressing neurons in which major portions of the dendritic tree were cut during tissue preparation were eliminated from the analysis. Because of the threedimensional geometry of the dendritic tree, some truncation is unavoidable. Although this method is likely to underestimate the overall size of the dendritic tree, it is a accurate measure of dendritic arbor, used by many investigators, that can be used to compare groups of animals (Kurz et al., 1986; Kalb, 1994). Criteria for inclusion of a neuron in this study are as follows: (1) the neuron is aspiny and located within the ventral horn, (2) the dendrites are radially distributed $\left(>180^{\circ}\right)$, and (3) no more than one dendrite is truncated (less than three cell body diameters). The number of transgene-expressing neurons per animal is small (Neve et al., 1997), and thus we were able to find on average only one neuron that fulfilled these criteria from approximately every other animal injected with virus.

DiI labeling. The lipophilic fluorochrome DiI (Molecular Probes) was injected postfixation into the ventral roots of the lumbar spinal cord, and cords were incubated at $37^{\circ} \mathrm{C}$ for $10-14 \mathrm{~d}$ (Inglis et al., 1998). Cords were sectioned $(80 \mu \mathrm{m})$, mounted onto glass slides, and viewed using epifluorescent optics, and neurons were traced using Neurolucida. A minimum 20 neurons were analyzed from each experimental group with the "Neurolucida" morphometry system (MicroBrightfield) using camera lucida. Approximately three DiI-labeled cells per animal fulfilled the above criteria and could be drawn and added to the database.

Statistics. Statistical comparisons of neuronal characteristics in cells expressing transgenes were compared using ANOVA, using the harmonic mean to account for differences between group numbers. For Sholl 
analyses and analyses of data according to dendrite order, neurons were compared using repeated measures ANOVA, with length, or dendrite order, as the repeated measure. After ANOVA or repeated measures ANOVA, post hoc comparisons between groups were made using Scheffé's $F$ test (Wallenstein et al., 1980).

In a separate series of experiments, comparisons between GluR1(Q)flip-expressing cells and DiI-labeled cells were performed using Student's unpaired $t$ test, with Bonferroni correction for multiple group comparisons.

\section{RESULTS}

In our test of the participation of GluR1flip in motor neuron dendrite morphogenesis, two preconditions needed be fulfilled. (1) The GluR1flip gene must be expressed after the period when activity-dependent alterations of dendrites occur. We operationally define such motor neurons as "mature." (2) A method was needed for quantifying the dendritic tree of transgene-expressing cells. We chose a $5 \mathrm{~d}$ time interval for our investigations, and studies were performed in vivo. The advantage of this approach is that it reflects growth or remodeling effects occurring with behaving animals on a time scale commensurate with the known critical period (Kalb and Hockfield, 1988; Kalb, 1994; Inglis et al., 1998). The cost of this advantage is that we lose the ability to see changes in dendrite shape that occur over a time frame of seconds to hours. It is known that dendritic spine movements occur on a time scale of seconds (Dailey and Smith, 1996; Fischer et al., 1998), and dendrite branch additions and subtractions occur on a time scale of minutes/hours (Rajan and Cline, 1998; Wu and Cline, 1998). Thus, the focus of this work is on larger scale, longer term net alterations in dendrites.

To determine when rat motor neurons had achieved their mature dendritic architecture, we quantitatively analyzed motor neuron dendrites labeled with the fluorescent tracer DiI. Comparison of DiI-labeled cells drawn from 23- and 28-d-old animals (Fig. 1) revealed no morphological differences between these groups, indicating that development of mature patterns of dendritic arbor as assayed with DiI was complete by $23 \mathrm{~d}$. This complements and extends previous work demonstrating no significant differences between the dendritic tree of P28 animals and $3+$ month animals (Kalb, 1994). We also found that administration of the NMDA antagonist MK-801 from P23 to P28 did not affect dendritic morphology (Fig. 1). We used an MK-801 dosage regime shown previously to reduce dendritic arbor in younger animals (Kalb, 1994; Inglis et al., 1998). These results confirm that motor neurons have reached their mature phenotype by P23 and are no longer undergoing large-scale activity-dependent alterations in branching pattern.

When neurons were infected with a virus engineered to express the LacZ gene, processed immunohistologically, and quantified, we were able to compare motor neuron dendrites identified by two different methods. We found no differences in any of our quantitative measures between the motor neuron dendritic trees of expressing $\beta$-galactosidase from P23 to P28 as compared with DiI-labeled P28 motor neurons (Fig. 1). These results indicate that our viral vector method of introducing genes into motor neurons does not adversely affect the health of the cells, and the transgene labeling method per se does not measurably alter the dendritic arbor.

The two variants of GluR1flip used in this study differed only in the amino acid occupying the $\mathrm{Q} / \mathrm{R}$ editing site. GluR1(Q)flip exists in nature, whereas GluR1(R)flip does not and to our knowledge has not been characterized previously. Before generating viral vectors capable of expressing these receptor subunits
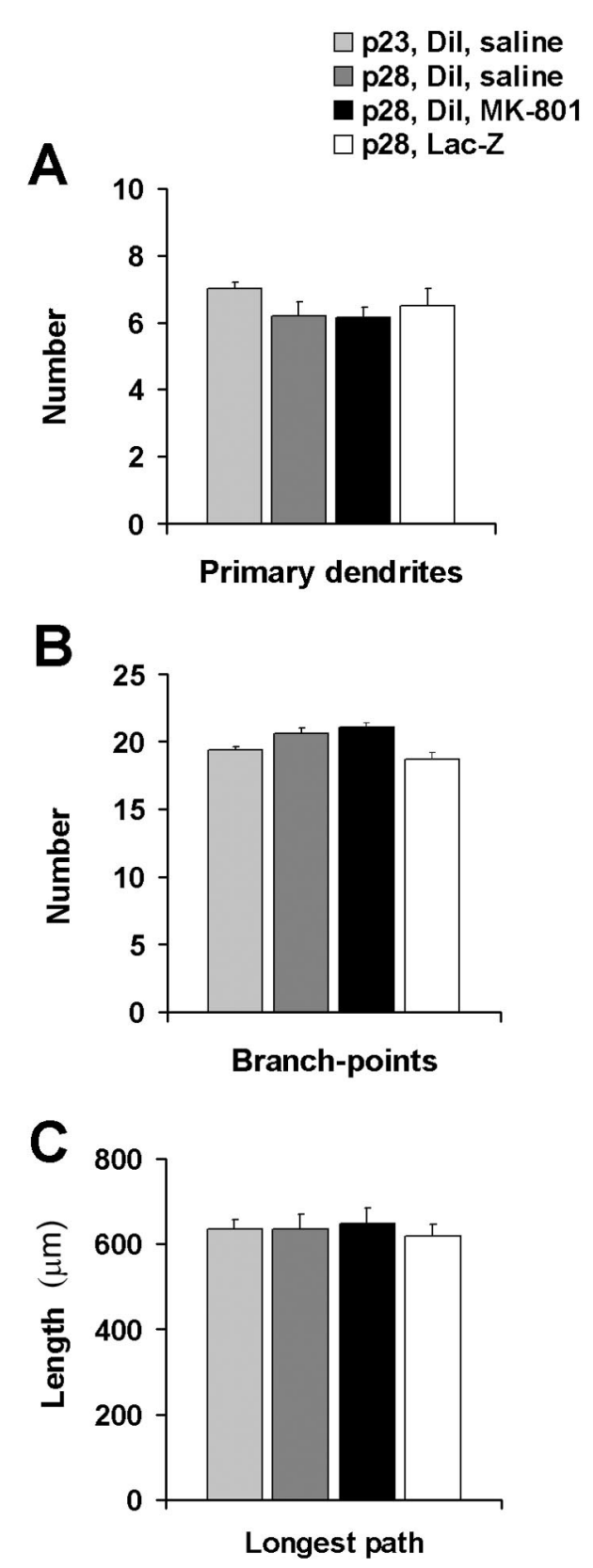

Figure 1. Comparison of morphological indices of DiI-labeled neurons from 23- and 28-d-old rats indicates that motor neurons develop their mature phenotype by age $23 \mathrm{~d}$. No effect on motor neuron morphology was observed after administration of the NMDA antagonist MK-801 or in response to viral-mediated expression of $\mathrm{LacZ}$ in motor neurons. $A$, Number of primary dendrites; $B$, number of branch-points per cell; $C$, longest dendritic path per cell.

in motor neurons, we performed an electrophysiological study and side-by-side comparison of the functional properties of the two subunits in Xenopus oocytes. The results demonstrate that GluR1(Q)flip is highly calcium permeable (Fig. 2A) with a rectifying $I-V$ relationship (Fig. $2 D$ ), whereas GluR1(R)flip shows mostly reduced currents, is virtually calcium-impermeable (Fig. $2 B$ ), and has a linear $I-V$ (Fig. $2 E$ ). The significantly reduced currents at GluR(R) receptors compared with $\operatorname{GluR}(\mathrm{Q})$ are a consequence of the substantially lower single-channel conductances of GluR(R) versions (Swanson et al., 1997). Coexpression 
A
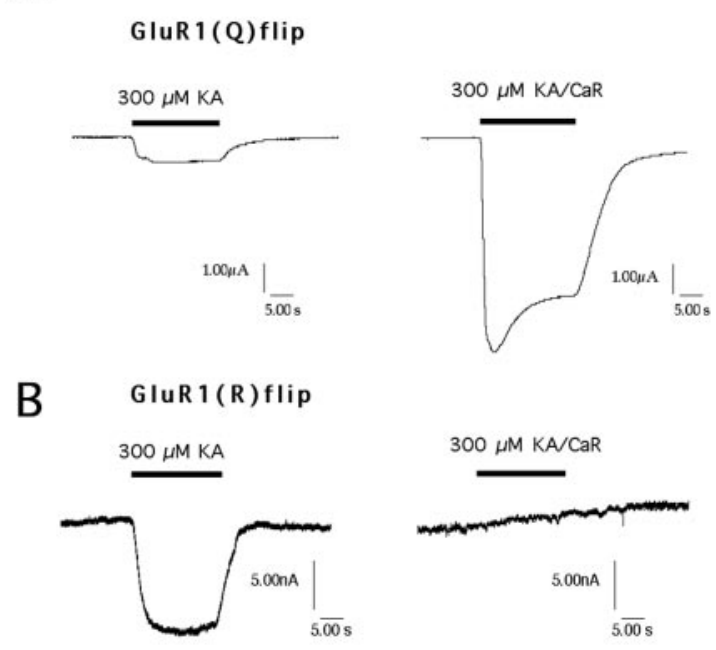

B

C

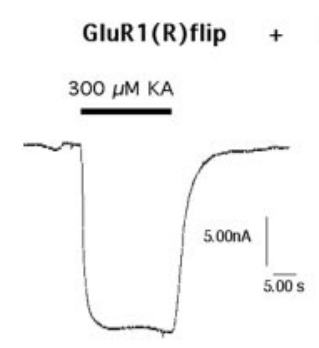

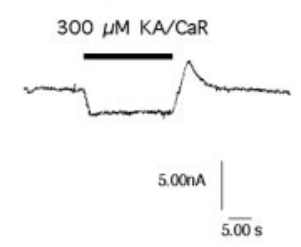

GluR1(Q)flip 1:1
D

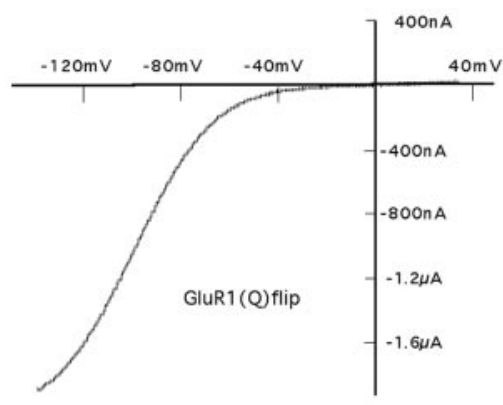

$\mathrm{E}$

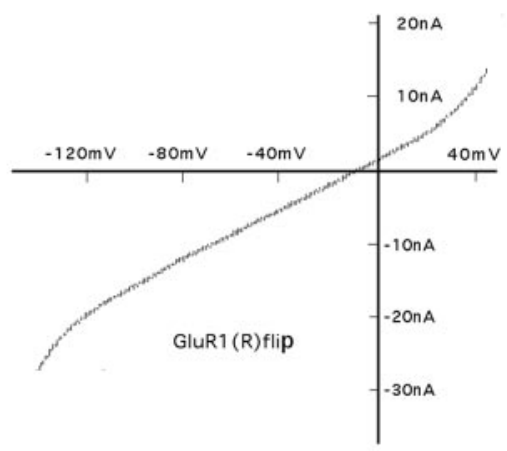

$\mathrm{F}$

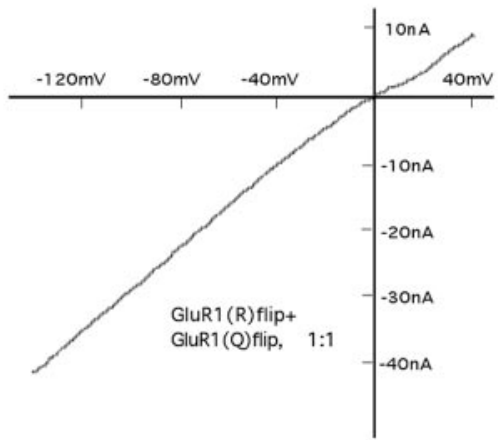

Figure 2. Comparison of steady-state responses $(A-C)$ and $I-V$ relationships $(D-F)$ of wild-type GluR1(Q)flip $(A, D)$, mutant GluR1(R)flip $(B, E)$, and a 1:1 mix of mutant and wild type $(C, F)$ recorded in Xenopus oocytes. Kainate $(K A ; 300 \mu \mathrm{M})$ was used as the agonist, either in normal Ringer's $(l e f t$ traces in $A-C$ ) or in calcium Ringer's $(C a R)$ (right traces in $A-C$ ). GluR1(Q)flip receptor channels have steady-state currents in the microampere range, whereas GluR1(R)flip receptor channels yield nanoampere range currents (note scale bars). The steady-state current when GluR1(R)flip is coexpressed with GluR1(Q) is also in the nanoampere range. The gentle upslope in B, right-hand panel, represents a slight reduction over time of the holding current ("leak current") and is typically found when oocytes are bathed in calcium Ringer's containing $80 \mathrm{~mm}$ calcium. Inspection of $D$ and $E$ reveals that the mutant GluR1(R)flip, contrary to wild-type GluR1(Q)flip, has a linear $I-V$ curve, and on coexpression with wild-type GluR1(Q)flip, linearizes the $I-V$ curve of the heteromeric complex. Coexpression also dramatically decreases the permeability to calcium.

of the two subunits leads to heteromeric receptors with increased maximal current amplitudes and a low calcium permeability (Fig. $2 C$ ) as well as a linear $I-V$ (Fig. $2 F$ ), demonstrating that GluR1(R)flip dominates the functional properties when coassembled with GluR1(Q)flip. Thus, the mutant GluR1(R)flip behaves exactly like wild-type GluR2 receptors, which naturally occur in the edited (R) form (Hume et al., 1991; Verdoorn et al., 1991). The advantage that the mutant GluR1(R)flip offers over GluR2 for this study lies in the presumably unbiased coassembly with GluR1 wild type, allowing manipulation of the functional properties of AMPA receptor complexes in vivo independent of potential subunit-specific sorting mechanisms.

Viral-mediated expression of GluR1(Q)flip and GluR1(R)flip had significant effects on several aspects of motor neuron architecture (Table 1), compared with LacZ, but the pattern of effects differed with respect to the transgene expressed (Fig. 3). The most prominent finding was that GluR1(Q)flip expression resulted in significantly greater numbers of branch-points and branch tips in comparison with GluR1(R)flip or LacZ. In addition, GluR1(Q)flip expression was associated with a reduction in the "longest dendritic path per cell," estimated by measuring the length of dendrite to the farthest branch tip from the cell body, a marker of how far from the cell body a dendrite is able to grow. Notably, there were no significant differences between groups in the total amount of dendritic arbor per cell, suggesting that the absolute amount of dendritic arbor supported by a cell remains constant, regardless of transgene expression, and that dendrite outgrowth is redistributed in GluR1-expressing neurons. GluR1(Q)flip and GluR1(R)flip expression tended to increase the soma area and the number of primary dendrites per cell, compared with LacZ controls, the magnitude of these changes attaining significance in GluR1(R)flipexpressing neurons (Fig. 3).

To assess whether dendritic arbor is redistributed within a particular region of the cell arbor, we performed a modified Sholl 
Table 1. Effects of transgene expression on the architecture of motor neuron dendrites

\begin{tabular}{|c|c|c|c|c|}
\hline Neuron parameter & LacZ & GluR1(Q)flip & GluR1(R)flip & $F_{(2,70)} ; p$ \\
\hline Primary dendrites & $5.7 \pm 0.4$ & $6.9 \pm 0.4$ & $7.9 \pm 0.4^{*}$ & $F=7.642 ; p=0.001$ \\
\hline Branch-points & $15.1 \pm 1.5$ & $20.4 \pm 1.4^{*} \dagger$ & $12.0 \pm 0.9$ & $F=12.12 ; p<0.001$ \\
\hline Branch tips & $21.1 \pm 1.9$ & $28.1 \pm 1.6^{*} \dagger$ & $20.5 \pm 1.1$ & $F=8.141 ; p<0.001$ \\
\hline Total dendrite arbor per cell $(\mu \mathrm{m})$ & $3173 \pm 311$ & $3231 \pm 256$ & $3065 \pm 248$ & $F=0.105 ; p=0.900$ \\
\hline Longest dendritic path $(\mu \mathrm{m})$ & $608 \pm 40$ & $424 \pm 27^{*}$ & $518 \pm 28$ & $F=9.661 ; p<0.001$ \\
\hline Cross-sectional soma area $\left(\mu \mathrm{m}^{2}\right)$ & $1427 \pm 171$ & $1907 \pm 125$ & $1980 \pm 137^{*}$ & $F=8.141 ; p<0.001$ \\
\hline
\end{tabular}

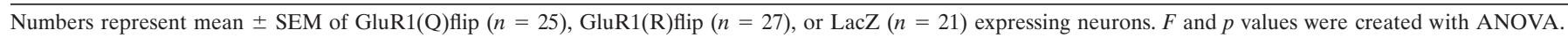

* Significant difference from LacZ; † significant difference from GluR1(R)flip (Scheffé post hoc test).

Figure 3. Representative examples of camera lucida drawings of transgeneexpressing motor neurons. These neuron drawings come from the lumbar spinal cord of P28 rats killed 5 d after injection of viral vectors into the sciatic nerve. Transgene-expressing cells were detected immunohistochemically, using primary antibodies against GluR1 or $\beta$ galactosidase. The three columns of three drawings correspond to motor neurons expressing GluR1(Q)flip, GluR1(R)flip, or LacZ, respectively. Scale bar, $100 \mu \mathrm{m}$.

analysis (Sholl, 1953), in which dendritic arbor is measured as a function of radial distance from cell body. Using consecutive radial bins of $50 \mu \mathrm{m}$, Sholl analysis revealed differences in the distribution of dendritic arbor, with a larger portion of dendritic arbor occurring closer to the cell body in cells expressing GluR1(Q)flip compared with other groups (Fig. 4A). In contrast, there were no significant differences between groups in the total amount of dendritic arbor as measured by the area under curve for the data present in Figure $4 A$. This indicates that although redistribution of dendrite had taken place in GluR1(Q)flipexpressing cells, the total amount of dendritic arbor supported by a cell was preserved in each experimental group.

Sholl analysis also confirmed that there were significant differences between groups in the number of branch-points (Fig. 4B), with significantly more branch-points in motor neurons overexpressing GluR1(Q)flip than in GluR1(R)flip-expressing cells or the LacZ controls. The increased number of branch-points in the
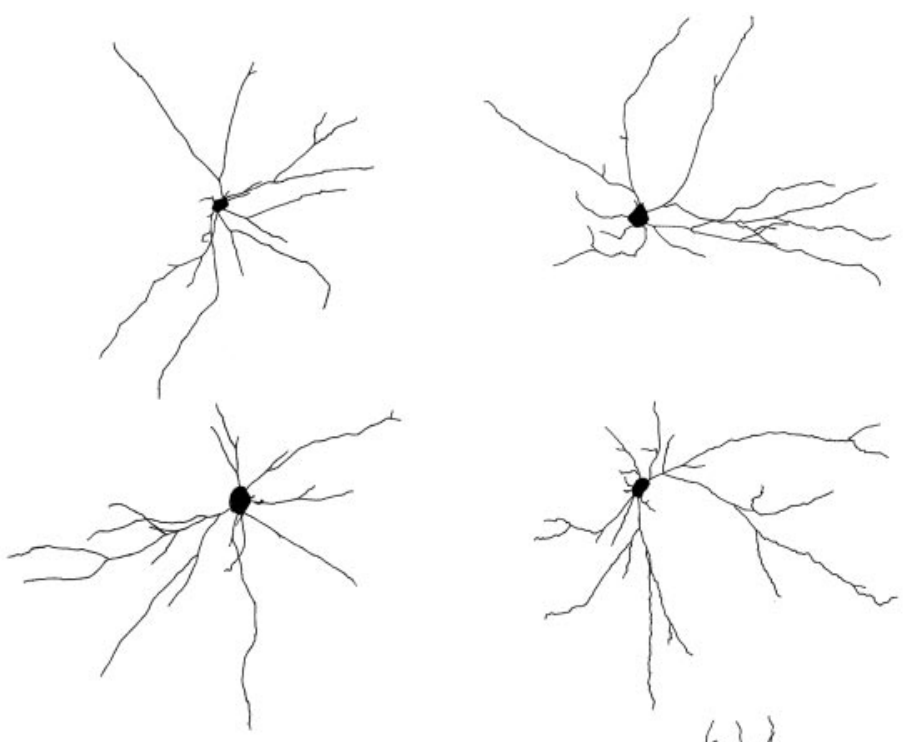

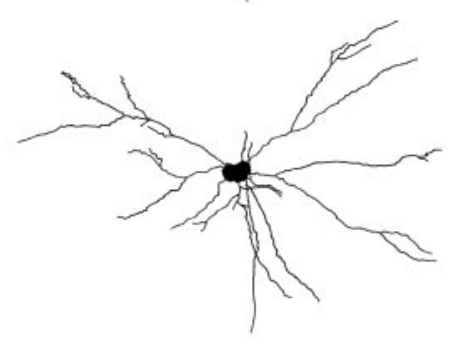

GluR1(R)flip
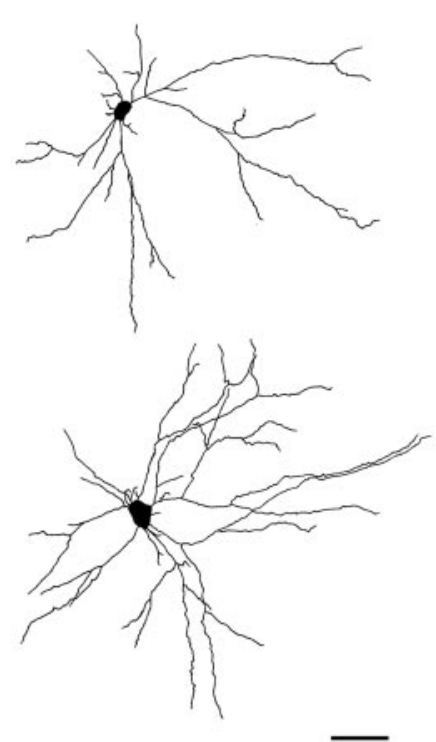

LacZ
GluR1(Q)flip-expressing cells was limited to short distances from the cell body (Fig. 4B).

Sholl analyses verify that overexpression of GluR1 results in redistribution of dendritic arbor across the extent of the cell by the addition of branch-points, whereas the total amount of dendritic arbor is preserved. One explanation for this is that existing dendritic arbor had been redistributed in cells expressing GluR1(Q)flip, rather than simply the addition of extra branch segments. To test this, we analyzed the number and size of individual dendritic segments according to their branch order (Fig. 5). These analyses demonstrated that cells expressing GluR1(Q)flip have significantly greater numbers of branch segments, of second order and higher, compared with LacZ. In contrast, however, the sizes of branch segments were significantly reduced in GluR1(Q)flip-expressing cells compared with GluR1(R)flip-expressing cells and LacZ controls. These results confirm that the precise morphological consequences of GluR1 
A

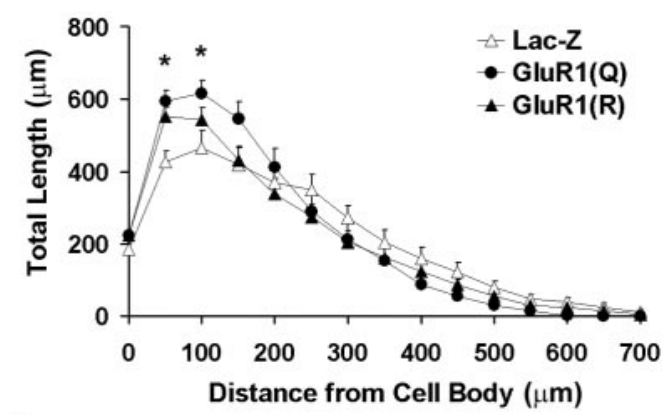

B

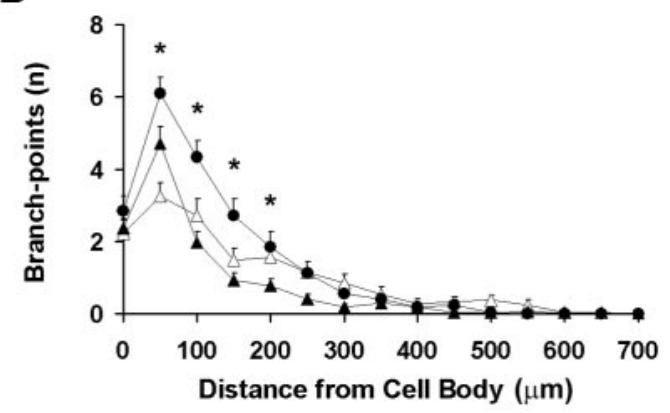

Figure 4. Sholl analysis of transgene-expressing motor neurons in the lumbar spinal cord. $A$, Total amount of dendritic arbor per cell. $\bullet$, GluR1(Q)flip; $\Delta$, GluR1(R)flip; $\triangle$, LacZ control. Repeated measures ANOVA revealed significant group $\times$ radius interaction $\left(F_{(28,980)}=3.478\right.$; $p<0.001$ ), with more dendritic arbor occurring closer to the cell body in cells expressing GluR1(Q)flip compared with other groups (Scheffé's post hoc test). In contrast, there was no significant difference between groups (area under curve; $\left.F_{(2,70)}=0.104 ; p=0.902\right)$. $B$, Number of branch-points per cell, expressed as a function of distance from the cell body. Analyses confirmed both group differences [area under curve $\left(F_{(2,70)}=12.123 ; p<\right.$ $0.001)$ and a group $\times$ radius interaction $\left.\left(F_{(28,980)}=5.127 ; p<0.001\right)\right]$, with significantly greater numbers of branch-points occurring in GluR1(Q)flip-expressing cells relative to other groups. Asterisks represent individual radial bins in which variance within groups were measured.

expression rely on editing at the $\mathrm{Q} / \mathrm{R}$ site and suggest that expression of GluR1(Q)flip results in the rearrangement of dendritic arbor, to allow for the addition of branch segments.

Enhanced conductance through AMPA receptors in transgene GluR1-expressing cells may increase ligand-receptor-mediated membrane depolarization. This would increase the activation of NMDA receptors, the receptor system previously implicated in motor neuron dendrite morphogenesis (Inglis et al., 1998). To test whether the altered dendritic morphology characteristic of GluR1(Q)flip overexpression is a result of increased NMDA receptor activity, we examined the dendrite remodeling effect of GluR1(Q)flip in animals receiving a noncompetitive pharmacologic antagonist of NMDA receptors (MK-801) or vehicle.

To first determine whether intraperitoneal administration of 1 $\mathrm{mg} / \mathrm{kg}$ MK-801 penetrates into the CNS at a dose sufficient to block NMDA receptors in young animals, we tested whether this dose of the drug blocked LTP in the dentate gyrus region of the hippocampus. Using adult animals, we have previously shown LTP in this region to be NMDA receptor dependent and blocked by MK-801 (Abraham and Mason, 1988). In the present experiment using P26-29 rats, we observed that vehicle-injected animals $(n=4)$ showed a $36 \pm 6 \%$ induction of LTP, measured 60 min after HFS (Fig. 6). In contrast, MK-801-injected animals showed no LTP $(-10 \pm 4 \% \operatorname{LTP} ; n=4)$. Statistical analysis
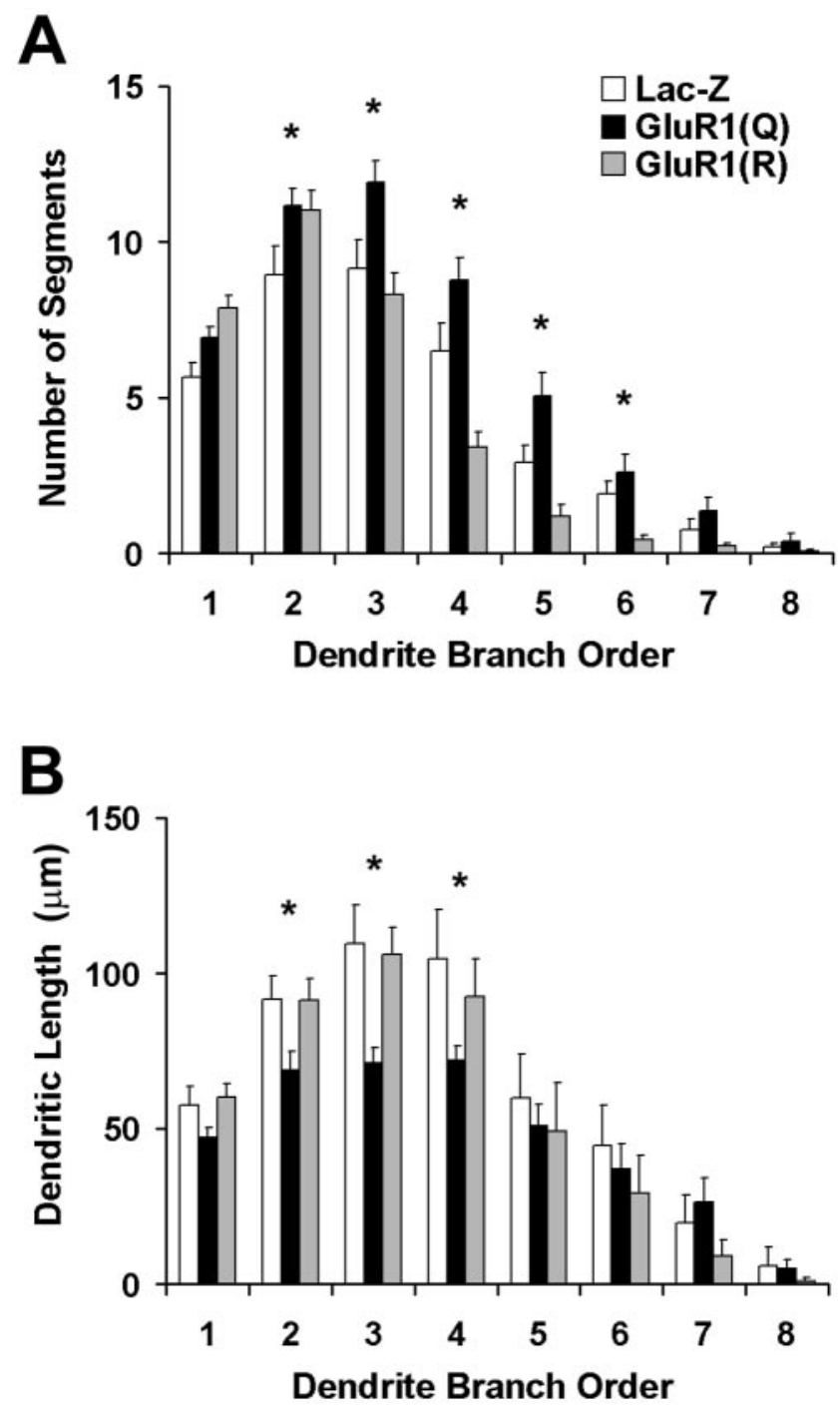

Figure 5. Comparison of dendrite morphology in transgene-expressing motor neurons as a function of branch order: primary dendrites emanate directly from the cell body; branching within a primary dendrite produces secondary dendrites and so on. Filled bars represent GluR1(Q)flipexpressing cells, shaded bars represent GluR1(R)flip-expressing cells, and unfilled bars represent LacZ controls. A, Number of dendrites of each order. Repeated measures ANOVA demonstrates significant differences in the number of dendritic segments $\left(F_{(14,490)}=7.739 ; p<0.001\right)$, with a greater number of segments found in GluR1(Q)flip-expressing neurons compared with other groups (Scheffé's post hoc test). B, Average length of each branch. Repeated measures ANOVA revealed significant group differences in the average size of each dendritic segment $\left(F_{(2,70)}=3.291\right.$; $p=0.043$ ), with segments of GluR1(Q)flip-expressing cells displaying shorter segment sizes than GluR(R)flip-expressing neurons or LacZ controls. Asterisks represent individual radial bins in which variance within groups was measured.

revealed that the degree of response change after HFS was significantly different between the two groups $\left(t_{(3)}=6.13 ; p<\right.$ 0.01). These data confirm that, at the dose used, MK- 801 penetrated into the brain sufficiently to block NMDA receptor function.

In the final series of experiments, MK-801 was administered daily to 23-d-old rats that received sciatic injections of HSVGluR1(Q)flip. Administration of MK-801 at this age does not itself result in reductions in dendritic arbor (Fig. 1), which is 

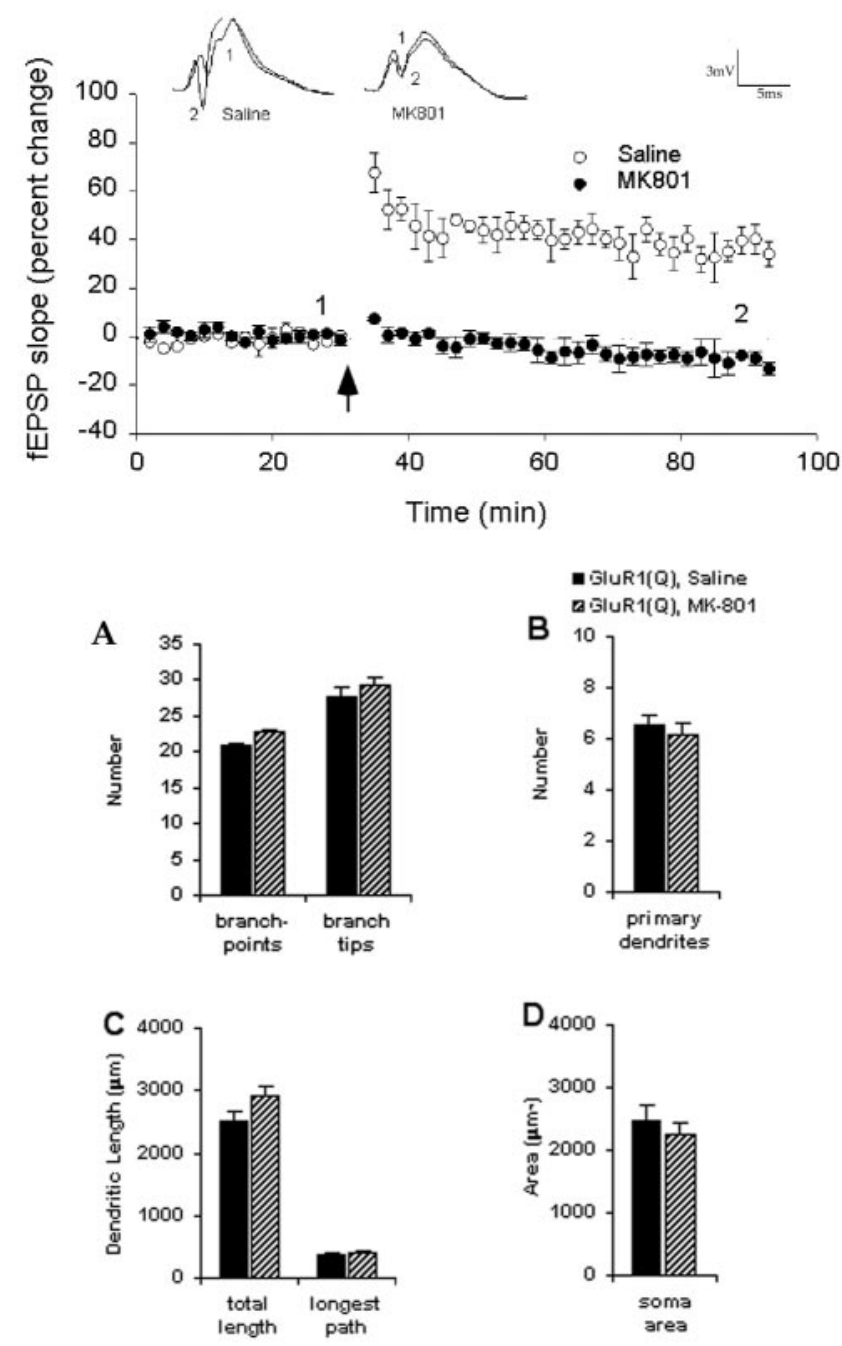

Figure 6. Plot of fEPSP slope measurements expressed as percentage change from baseline as recorded before and after HFS (arrow). Data have been averaged in 2 min bins for individual animals and then averaged across animals for each group and expressed as mean \pm SEM. LTP was induced in vehicle-treated animals $(\bigcirc)$ but blocked in MK-801treated animals $(\bullet)$. Inset waveforms are averages of 30 responses taken at the times indicated before and after HFS. Calibration: $3 \mathrm{mV}, 5 \mathrm{msec}$. Administration of the NMDA receptor antagonist MK-801 has no effect in cells expressing GluR1(Q)flip during late postnatal development. Graph illustrates quantification of GluR1(Q)flip-expressing cells from animals treated with saline or MK-801: number of branch-points and branch tips $(A)$; number of primary dendrites $(B)$; total arbor and longest dendritic path per cell $(C)$; and soma area $(D)$. MK-801 or saline was administered subcutaneously once a day for $5 \mathrm{~d}$ after viral-mediated transfection of GluR1(Q)flip into lumbar spinal cord motor neurons.

characteristic of NMDA antagonist administration in younger animals (Kalb, 1994; Inglis et al., 1998). Coadministration of MK-801 during GluR1(Q)flip transgene expression did not prevent the dendrite remodeling effects of GluR1(Q)flip expression (Fig. 6), suggesting that AMPA receptor-mediated effects on dendritic morphology in these animals are produced independently of NMDA receptor activation.

\section{DISCUSSION}

In these studies we reintroduced into mature motor neurons a developmentally regulated glutamate receptor subunit normally expressed in great abundance by neonatal motor neurons. The major finding of this series of experiments is that expression of GluR1 in motor neurons at a time when dendritic architecture is mature leads to a remodeling of the dendritic arbor. One implication of these findings is that the biochemical and cellular machinery required to modify motor neuron dendrite architecture is present in mature motor neurons and, with the appropriate stimulus, can be engaged. GluR1 is sufficient to initiate the plasticity otherwise restricted to the neonatal activity-dependent critical period. A second implication of this work derives from the observation that electrophysiologically different versions of GluR1 have distinct effects on dendrites. This suggests that the establishment of dendritic geometry results from a collection of morphogenic events that can be independently regulated, at least in part.

Several technical considerations are engendered by these experiments. Because we are using viral vectors it is important to have confidence that this method of gene transfer is not introducing an extra variable into the experiments. Our initial characterization of the HSV-GluR1(Q)flip shows that the method for infecting motor neurons by intranerve virus injection does not cause damage to the neuromuscular unit (Neve et al., 1997). A high level of transgene expression can be achieved this way, starting 12-18 hr after infection, and is sustained for at least $7 \mathrm{~d}$ in vivo. In the case of HSV-GluR1(Q)flip, functional GluR1containing AMPA receptors are expressed on the motor neuron cell surface (Neve et al., 1997). It is likely that virally transduced GluR1 subunits populate AMPA receptors on the cell body as well as synaptic and extrasynaptic sites (Shi et al., 1999; Passafaro et al., 2001). These results, in combination with a direct comparison of DiI-labeled motor neurons with immunohistology for $\beta$-galactosidase-labeled motor neurons (Table 1), is strong evidence that this method of gene transfer does not introduce artifact.

In addition to altering the electrophysiological phenotype of HSV-GluR1(Q)flip-infected motor neurons, we use the GluR1 protein as a reporter of dendritic architecture. This is possible because there is low or absent endogenous GluR1 protein expression in motor neurons at this age (Jakowec et al., 1995a). Immunohistologically, transgene GluR1 intensely labels the dendritic arbor, and it is unlikely that it selectively avoids particular segments of the tree. Without an independent method for labeling the tree, we cannot state unequivocally that the distal-most portions of the tree are filled by the transgene and thus detectable. Quantitatively, most of the dendritic tree is within $\sim 400 \mu \mathrm{m}$ of the cell body, and our major findings relate to this portion of the dendritic tree. In addition, our modified Scholl analysis (Figs. 4, 5) indicates that dendritic length of fifth and higher order dendrites was the same regardless of whether the neuron was expressing GluR1(Q)flip, GluR1(R)flip, or $\beta$-galactosidase. Thus, the biological effects of the two forms of GluR1 are restricted to a spatial domain within $250 \mu \mathrm{m}$ from the cell body. For these reasons, even if the distal-most portions of the tree of HSVGluR1-infected motor neurons are truncated for technical reasons, it is unlikely to have an important impact on our results.

Investigations of activity-dependent development of neurons within several regions of the nervous system have focused on the involvement of the NMDA receptor (Crair and Malenka, 1995; Kirkwood et al., 1995; Zhang et al., 2000). For example, NMDA antagonists disrupt the formation of ocular dominance columns in the visual cortex (Kleinschmidt et al., 1987; Bear et al., 1990) and other visual centers (Cline et al., 1987; Scherer and Udin, 1989), whereas application of the agonist NMDA sharpens the 
boundaries of eye-specific visual fields (Yen et al., 1993, 1995). Motor neurons similarly undergo NMDA receptor-mediated molecular and morphologic development during a critical period in early postnatal life (Kalb and Hockfield, 1990; Kalb, 1994). Because motor neurons, and other neurons within the segmental spinal cord (Kalb et al., 1992; Stegenga and Kalb, 2001), express NMDA receptors at the time of our experimental manipulation of GluR1 expression, it is plausible that NMDA receptors participated in the dendrite remodeling effects that we found. Our experiments using systemically administered MK-801 make this unlikely. We and others (Abraham and Mason, 1988; Gilbert and Mack, 1990; Morimoto et al., 1991; Robinson and Reed, 1992; Markevich et al., 1997; Leung and Shen, 1999; Morgan and Teyler, 1999) have shown that systemically administered M K-801 (dosing range, 0.1-1.0 mg/kg) blocks NMDA receptors (Fig. 6). During the interval from P23 to P28, both dentate gyrus neurons (Monyer et al., 1994) and spinal motor neurons (Stegenga and Kalb, 2001) express NMDA receptors composed of heterooligomers of NR1-NR2A. Because MK-801 blocked LTP in the hippocampus of animals at these young ages (Fig. 6), the simplest inference is that MK-801 also blocked the high-affinity NMDA receptors on motor neurons (Kalb et al., 1992; Laurie and Seeburg, 1994). Furthermore, we previously have used this dosing regimen in animals that were 1-2 weeks younger and found significant dendrite remodeling effects (Kalb, 1994; Inglis et al., 1998). Thus several lines of evidence argue against the participation of NMDA receptors in the GluR1(Q)flip dendrite remodeling that we have found. Our present results are most consistent with the idea that activation of AMPA receptors can be a key determinant of the morphogenesis of motor neuron dendrites. Because the abundance of GluR1 subunits is great in young animals during the period in which motor neurons attain their mature architecture (Jakowec et al., 1995a), GluR1 expression by motor neurons may be one of the reasons the critical period of plasticity is restricted to early postnatal life.

We found that the precise features of dendritic morphology rely on specific electrophysiological properties of AMPA receptors composed of GluR1. GluR1(Q)flip resulted in rearrangement of the dendritic tree, with the addition of branch-points and segments close to the cell body, at the expense of distal portions of the tree. In contrast, GluR1(R)flip did not produce an increased number of branch-points but increased the number of primary dendrites emanating from the cell body and the cell body size. It has been proposed that the composition of AMPA receptors is determined in a combinatorial manner (Geiger et al., 1995), and therefore the precise electrophysiological properties of endogenous AMPA receptors will depend on the relative expression levels of individual subunits. This suggests that the endogenous downregulation of GluR1(Q)flip expression in developing motor neurons would increase the relative contribution of GluR2 to AMPA receptors. This could occur by reducing the number of homomeric GluR1 receptors, by diminishing the percentage contribution of GluR1 into heteromeric receptors, or by both mechanisms. As a result of this, there would be an anticipated reduction of receptors displaying high calcium permeability and large unitary conductances.

The mechanism underlying the modest effect of GluR1(R) that we found on dendritic structure (in comparison with LacZexpressing neurons) is a matter of speculation. The effects of this form of GluR1 (never seen in nature) might be tied to its electrophysiologic properties (such as low conductance and linear $I-V$ relationship) or perhaps to the ability of GluR1(R) to recruit other proteins (such as SAP97 and 4.1N,G) (Leonard et al., 1998; Shen et al., 2000) to the plasmalemma.

It seems unlikely that a simple "trophic" effect of more cell AMPA receptors would explain our findings (Vaughn et al., 1988) because the expression of GluR1(Q)flip in motor neurons apparently does not alter the overall size of the dendrite tree. Instead there appears to be a redistribution of a fixed amount of dendritic membrane with more branching occurring closer to the cell body. Notwithstanding this, the high conduction of activated GluR1 receptors as well as other phenotypic features (such as rectification and desensitization), in addition to calcium permeability, may also be an important signal for dendrite remodeling. The ability to manipulate these variables independently of calcium conductance will permit future exploration of this issue (Curutchet et al., 1992; Ferrer-Montiel et al., 1996; Stern-Bach et al., 1998).

Previous investigators who have introduced GluR1 into neurons (by transfection or viral vectors) have found that it incorporates into synaptic as well as extra-synaptic cell surface AMPA receptors. There is complex regulation of GluR1-containing AMPA receptors by endocytosis and exocytosis and the movement between extrasynaptic and synaptic domains over the cell surface membrane (Beattie et al., 2000; Lin et al., 2000; Man et al., 2000; Passafaro et al., 2001; Shi et al., 2001). The differences between various in vitro (dissociated neurons versus slice cultures) and in vivo experimental preparations make direct extrapolation between studies difficult. Nevertheless, it is clear that transgene GluR1 has the capacity to incorporate into synaptic AMPA receptors.

From studies of rats that were reared in the presence or absence of gravity, we have found evidence for experiencedependent sculpting of the motor neuron dendritic tree (Inglis et al., 2000). Compelling investigations performed in monkeys, cats, ferrets, and rodents have provided strong support for the idea that experience-dependent specification of synaptic connectivity and distribution, size, and complexity of axonal/dendritic arbors is mediated by the environmentally evoked patterns and level of synaptic activity (for review, see Shatz, 1990; Goodman and Shatz, 1993; Jessell and Kandel, 1993; Katz and Shatz, 1996; Bi and Poo, 2001; Zhang and Poo, 2001). As noted above, activation of synaptic NMDA receptors can play a key role in this process. In consideration of this framework, one scenario is that synaptic activation of AMPA receptors containing transgene GluR1 underlies the restructuring of the motor neuron dendritic tree. Synaptic plasticity mediated by activation of calcium-permeable AMPA receptors is known to occur in the spinal cord ( $\mathrm{Gu}$ et al., 1996). Transgene GluR1 might engage the same cellular machinery normally used during early postnatal life to establish dendritic architecture, raising the possibility that such processes are involved in the dendritic remodeling that we see (ConstantinePaton et al., 1990; Cline, 1998; Constantine-Paton and Cline, 1998).

The involvement of calcium-permeable AMPA receptors in experience-dependent structural modification of dendrites has been described previously in retinal horizontal cells (Okada et al., 1999). The normal expression of calcium-permeable AMPA receptors in early postnatal motor neurons (Carriedo et al., 1996; Bar-Peled et al., 1999; Vandenberghe et al., 2000a,b) may lead to an increased number of dendritic branch-points, and the subsequent reduction in GluR1 subunit abundance may promote maintenance of stable branch segments. The outcome of this dynamic situation could result in fine-tuning descending and segmental 
synaptic connections in the motor system for greater functional efficiency.

\section{REFERENCES}

Abraham WC, Mason SE (1988) Effects of the NMDA receptor/channel antagonists CPP and MK-801 on hippocampal field potentials and long-term potentiation in anesthetized rats. Brain Res 462:40-46.

Bar-Peled O, O'Brien RJ, Morrison JH, Rothstein JD (1999) Cultured motor neurons possess calcium-permeable AMPA/kainate receptors. NeuroReport 10:855-859.

Bear MF, Kleinschmidt A, Gu Q, Singer W (1990) Disruption of experience-dependent synaptic modifications in striate cortex by infusion of an NMDA receptor antagonist. J Neurosci 10:909-925.

Beattie EC, Carroll RC, Yu X, Morishita W, Yasuda H, von Zastrow M, Malenka RC (2000) Regulation of AMPA receptor endocytosis by a signaling mechanism shared with LTD. Nat Neurosci 3:1291-1300.

Bi G, Poo M (2001) Synaptic modification by correlated activity: Hebb's postulate revisited. Annu Rev Neurosci 24:139-166.

Bodnarenko SR, Chalupa LM (1993) Stratification of ON and OFF ganglion cell dendrites depends on glutamate-mediated afferent activity in the developing retina. Nature 364:144-146.

Burnashev N, Monyer H, Seeburg PH, Sakmann B (1992) Divalent ion permeability of AMPA receptor channels is dominated by the edited form of a single subunit. Neuron 8:189-198.

Carriedo SG, Yin HZ, Weiss JH (1996) Motor neurons are selectively vulnerable to AMPA/KA receptor-mediated injury in vitro. J Neurosci 16:4069-4079.

Cline HT (1998) Topographic maps: developing roles of synaptic plasticity. Curr Biol 8:R836-839.

Cline HT, Debski EA, Constantine-Paton M (1987) N-methyl-Daspartate receptor antagonist desegregates eye-specific columns. Proc Natl Acad Sci USA 84:4342-4345.

Constantine-Paton M, Cline HT (1998) LTP and activity-dependent synaptogenesis: the more alike they are, the more different they become. Curr Opin Neurobiol 8:139-148.

Constantine-Paton M, Cline HT, Debski E (1990) Patterned activity, synaptic convergence, and the NMDA receptor in developing visual pathways. Annu Rev Neurosci 13:129-154.

Crair MC, Malenka RC (1995) A critical period for long-term potentiation at thalamocortical synapses. Nature 375:325-328.

Curutchet P, Bochet P, deCarvalho LP, Lambolez B, Stinnakre J, Rossier J (1992) In the GluR1 glutamate subunit a glutamine to histidine point mutation suppresses inward rectification but not calcium permeability. Biochem Biophys Res Commun 182:1089-1093.

Dailey ME, Smith SJ (1996) The dynamics of dendritic structure in developing hippocampal slices. J Neurosci 16:2983-2994.

Everts I, Villmann C, Hollmann M (1997) N-glycosylation is not a prerequisite for glutamate receptor function but is essential for lectin modulation. Mol Pharmacol 52:861-873.

Ferrer-Montiel AV, Sun W, Montal M (1996) A single tryptophan on M2 of glutamate receptor channels confers high permeability to divalent cations. Biophys J 71:749-758.

Fischer M, Kaech S, Knutti D, Matus A (1998) Rapid actin-based plasticity in dendritic spines. Neuron 20:847-854.

Geiger JRP, Melcher T, Koh D-S, Sakmann B, Seeburg PH, Jonas P, Monyer H (1995) Relative abundance of subunit mRNAs determines gating and $\mathrm{Ca}^{2+}$ permeability of AMPA receptors in principal neurons and interneurons in rat CNS. Neuron 15:193-204.

Gilbert ME, Mack CM (1990) The NMDA antagonist, MK-801, suppresses long-term potentiation, kindling, and kindling-induced potentiation in the perforant path of the unanesthetized rat. Brain Res 519:89-96.

Goodman CS, Shatz CJ (1993) Developmental mechanisms that generate precise patterns of neuronal connectivity. Cell 10:77-98.

Gu JG, Albuquerque CJL, MacDermott AB (1996) Synaptic strengthening through activation of $\mathrm{Ca}^{2+}$-permeable AMPA receptors. Nature 381:793-796.

Hausser M, Spruston N, Stuart GJ (2000) Diversity and dynamics of dendritic signaling. Science 290:739-744.

Helmchem F (1999) Dendrites as biochemical compartments. In: Dendrites (Stuart G, Spruston N, Hausser M, eds), pp 161-186. Oxford: Oxford UP.

Hollmann M, Maron C, Heinemann S (1994) N-glycosylation site tagging suggests a three transmembrane domain topology for the glutamate receptor GluR1. Neuron 13:1331-1341.

Hume RI, Purves D (1981) Geometry of neonatal neurons and the regulation of synapse elimination. Nature 293:469-471.

Hume RI, Dingledine R, Heinemann SF (1991). Identification of a site in glutamate receptor subunits that controls calcium permeability. Science 253:1028-1031.

Inglis FM, Furia F, Zuckerman KE, Strittmatter SM, Kalb RG (1998) The role of nitric oxide and NMDA receptors in the development of motor neuron dendrites. J Neurosci 18:10493-10501.
Inglis FM, Zuckerman KE, Kalb RG (2000) Experience-dependent development of spinal motor neurons. Neuron 26:299-305.

Jackson PC, Frank E (1987) Development of synaptic connections between muscle sensory and motor neurons: anatomical evidence that postsynaptic dendrites grow into a preformed sensory neuropil. J Comp Neurol 255:538-547.

Jakowec MW, Fox AJ, Martin LJ, Kalb RG (1995a) Quantitative and qualitative changes in AMPA receptor expression during spinal cord development. Neuroscience 67:893-907.

Jakowec MW, Yen L, Kalb RG (1995b) In situ hybridization analysis of AMPA receptor subunit gene expression in the developing rat spinal cord. Neuroscience 67:909-920.

Jessell TM, Kandel ER (1993) Synaptic transmission: a bidirectional and self-modifiable form of cell-cell communication. Cell 72:1-30.

Jonas P, Racca C, Sakmann B, Seeburg PH, Monyer H (1994) Differences in calcium permeability of AMPA-type glutamate receptor channels in neocortical neurons caused by differential GluR-B subunit expression. Neuron 12:1281-1289.

Kalb RG (1994) Regulation of motor neuron dendrite growth by NMDA receptor activation. Development 120:3063-3071.

Kalb RG, Hockfield S (1988) Molecular evidence for early activitydependent development of hamster motor neurons. J Neurosci $8: 2350-2360$.

Kalb RG, Hockfield S (1990) Induction of a neuronal proteoglycan by the NMDA receptor in the developing spinal cord. Science 250:294-296.

Kalb RG, Lidow MS, Halsted MJ, Hockfield S (1992) N-methyl-DAspartate receptors are transiently expressed in the developing spinal cord ventral horn. Proc Natl Acad Sci USA 89:8502-8506.

Katz LC, Constantine-Paton M (1988) Relationships between segregated afferents and postsynaptic neurons in the optic tectum of threeeyed frogs. J Neurosci 8:3160-3180.

Katz LC, Shatz CJ (1996) Synaptic activity and the construction of cortical circuits. Science 274:1133-1138.

Kirkwood A, Lee H-K, Bear MF (1995) Co-regulation of long-term potentiation and experience-dependent synaptic plasticity in visual cortex by age and experience. Nature 375:328-331.

Kleinschmidt A, Bear MF, Singer W (1987) Blockade of "NMDA" receptors disrupts experience-dependent plasticity of kitten striate cortex. Science 238:355-358.

Korogod SM, Kulagina IB, Horcholle-Bossavit G, Gogan P, Tyc-Dumont S (2000) Activity-dependent reconfiguration of the effective dendritic field of motoneurons. J Comp Neurol 422:18-34.

Kurz EM, Sengelaub DR, Arnold AP (1986) Androgens regulate the dendritic length of mammalian motoneurons in adulthood. Science 232:395-398.

Laurie DJ, Seeburg PH (1994) Ligand affinities at recombinant $N$-methyl-D-aspartate receptors depend on subunit composition. Eur J Pharmacol 268:335-345.

Leonard AS, Davare MA, Horne MC, Garner CC, Hell JW (1998) SAP97 is associated with the alpha-amino-3-hydroxy-5-methylisoxazole4-propionic acid receptor GluR1 subunit. J Biol Chem 273:19518-19524.

Leung LS, Shen B (1999) $N$-methyl-D-aspartate receptor antagonists are less effective in blocking long-term potentiation at apical than basa dendrites in hippocampal CA1 of awake rats. Hippocampus 9:617-630.

Lim F, Hartley D, Starr P, Lang P, Song S, Yu L, Wang Y, Geller AI (1996) Generation of high-titer defective HSV-1 vectors using an IE 2 deletion mutant and quantitative study of expression in cultured cortical cells. BioTechniques 20:460-469.

Lin JW, Ju W, Foster K, Lee SH, Ahmadian G, Wyszynski M, Wang YT, Sheng M (2000) Distinct molecular mechanisms and divergent endocytotic pathways of AMPA receptor internalization. Nat Neurosci 3:1282-1290.

Magee JC (1999) Voltage-gated ion channels in dendrites. In: Dendrites (Stuart G, Spruston N, Hausser M, eds), pp 139-160. Oxford: Oxford UP.

Mainen ZF, Sejnowski TJ (1996) Influence of dendritic structure on firing pattern in model neocortical neurons. Nature 382:363-366.

Man HY, Lin JW, Ju WH, Ahmadian G, Liu L, Becker LE, Sheng M, Wang YT (2000) Regulation of AMPA receptor-mediated synaptic transmission by clathrin-dependent receptor internalization. Neuron 25:649-662.

Markevich V, Scorsa AM, Dawe GS, Stephenson JD (1997) Cholinergic facilitation and inhibition of long-term potentiation of CA1 in the urethane-anaesthetized rats. Brain Res 754:95-102.

McAllister AK, Lo DC, Katz LC (1995) Neurotrophins regulate dendritic growth in developing visual cortex. Neuron 15:791-803.

McAllister AK, Katz LC, Lo DC (1997) Opposing roles for endogenous BDNF and NT-3 in regulating cortical dendrite growth. Neuron 18:767-778

Monyer H, Burnashev N, Laurie DJ, Sakmann B, Seeburg PH (1994) Developmental and regional expression in the rat brain and functional properties of four NMDA receptors. Neuron 12:529-540.

Morgan SL, Teyler TJ (1999) VDCCs and NMDARs underlie two forms of LTP in CA1 hippocampus in vivo. J Neurophysiol 82:736-740. Morimoto K, Katayama K, Inoue K, Sato K (1991) Effects of competi- 
tive and noncompetitive NMDA receptor antagonists on kindling and LTP. Pharmacol Biochem Behav 40:893-899.

Neve RL, Howe JR, Hong S, Kalb RG (1997) Introduction of the glutamate receptor subunit 1 into motor neurons in vitro and in vivo using a recombinant herpes simplex virus. Neuroscience 79:435-447.

Nusser Z (1999) Subcellular distribution of neurotransmitter receptors and voltage-gated ion channel. In: Dendrites (Stuart G, Spruston N, Hausser M, eds), pp 85-113. Oxford: Oxford UP.

Okada T, Schultz K, Geurtz W, Hatt H, Weiler R (1999) AMPApreferring receptors with high $\mathrm{Ca}^{2+}$ permeability mediate dendritic plasticity of retinal horizontal cells. Eur J Neurosci 11:1085-1095.

Passafaro M, Piech V, Sheng M (2001) Subunit-specific temporal and spatial patterns of AMPA receptor exocytosis in hippocampal neurons. Nat Neurosci 4:917-926.

Purves D (1983) Modulation of neuronal competition by postsynaptic geometry in autonomic ganglia. Trends Neurosci 6:10-16.

Purves D, Hume RI (1981) The relation of postsynaptic geometry to the number of presynaptic axons that innervate autonomic ganglion cells. J Neurosci 1:441-452.

Rajan I, Cline HT (1998) Glutamate receptor activity is required for normal development of tectal cell dendrites in vivo. J Neurosci 18: $7836-7846$.

Robinson GB, Reed GD (1992) Effect of MK-801 on the induction and subsequent decay of long-term potentiation in the unanesthetized rabbit hippocampal dentate gyrus. Brain Res 569:78-85.

Scherer WJ, Udin SB (1989) $N$-methyl-D-aspartate antagonists prevent interaction of binocular maps in Xenopus tectum. J Neurosci 9:3837-3843.

Segev I (1998) Sound grounds for computing dendrites. Nature 393:207208.

Shatz CJ (1990) Impulse activity and the patterning of connections during CNS development. Neuron 5:745-756.

Shen L, Liang F, Walensky LD, Huganir RL (2000) Regulation of AMPA receptor GluR1 subunit surface expression by a $4.1 \mathrm{~N}$-linked actin cytoskeletal association. J Neurosci 20:7932-7940.

Shi S, Hayashi Y, Esteban JA, Malinow R (2001) Subunit-specific rules governing AMPA receptor trafficking to synapses in hippocampal pyramidal neurons. Cell 105:331-343.

Shi S-H, Hayashi Y, Petralia RS, Zaman SH, Wenthold RJ, Svoboda K, Malinow R (1999) Rapid spine delivery and redistribution of AMPA receptors after synaptic NMDA receptor activation. Science 284:18111816.

Sholl D (1953) Dendritic organization in neurons of the visual and motor cortices of the cat. J Anat (Lond) 87:387-406.

Sommer B, Kohler M, Sprengal R, Seeburg PH (1991) RNA editing in brain controls a determinant of ion flow in glutamate-gated channel. Cell 67:11-19.
Spruston N, Schiller Y, Stuart G, Sakmann B (1995) Activity-dependent action potential invasion and calcium influx into hippocampal CA1 dendrites. Science 268:297-300.

Stegenga SL, Kalb RG (2001) Developmental regulation of $N$-methyl-Daspartate- and kainate-type glutamate receptor expression in the rat spinal cord. Neuroscience 105:499-507.

Stern-Bach Y, Russo S, Neuman M, Rosenmund C (1998) A point mutation in the glutamate binding site blocks desensitization of AMPA receptors. Neuron 21:907-918.

Stuart G, Spruston N, Hausser M (1999) Dendrites. Oxford: Oxford UP.

Swanson GT, Kamboj SK, Cull-Candy SG (1997) Single-channel properties of recombinant AMPA receptors depend on RNA editing, splice variation, and subunit composition. J Neurosci 17:58-69.

Vandenberghe W, Robberecht W, Brorson JR (2000a) AMPA receptor calcium permeability, GluR2 expression, and selective motoneuron vulnerability. J Neurosci 20:123-132.

Vandenberghe W, Ihle EC, Patneau DK, Robberecht W, Brorson JR (2000b) AMPA receptor current density, not desensitization, predicts selective motoneuron vulnerability. J Neurosci 20:7158-7166.

Vaughn JE, Barber RP, Sims TJ (1988) Dendritic development and preferential growth into synaptogenic fields: a quantitative study of Golgi-impregnated spinal motor neurons. Synapse 2:69-78.

Verdoorn TA, Burnashev N, Monyer H, Seeburg PH, Sakmann B (1991) Structural determinants of ion flow through recombinant glutamate receptor channels. Science 252:1715-1718.

Vetter P, Roth A, Hausser M (2001) Propagation of action potentials in dendrites depends on dendritic morphology. J Neurophysiol 85: 926-937.

Wallenstein S, Zucker CL, Fleiss JL (1980) Some statistical methods useful in circulation research. Circ Res 47:1-9.

Wei DS, Mei YA, Bagal A, Kao JP, Thompson SM, Tang CM (2001) Compartmentalized and binary behavior of terminal dendrites in hippocampal pyramidal neurons. Science 293:2272-2275.

Wu G-Y, Cline HT (1998) Stabilization of dendritic arbor structure in vivo by CaMKII. Science 279:222-225.

Yen L, Sibley JT, Constantine-Paton M (1995) Analysis of synaptic distribution within single retinal axonal arbors after chronic NMDA treatment. J Neurosci 15:4712-4725.

Yen L-H, Sibley JT, Constantine-Paton M (1993) Fine-structural alterations and clustering of developing synapses after chronic treatments with low levels of NMDA. J Neurosci 13:4949-4960.

Zhang LI, Poo MM (2001) Electrical activity and development of neural circuits. Nat Neurosci [Suppl] 4:1207-1214.

Zhang LI, Tao HW, Poo M (2000) Visual input induces long-term potentiation of developing retinotectal synapses. Nat Neurosci 3: $708-715$. 